\title{
CHARACTERISATION OF THE MECHANICAL AND CORROSIVE PROPERTIES OF NEWLY DEVELOPED GLASS-STEEL COMPOSITES
}

\author{
KARAKTERIZACIJA MEHANSKIH IN KOROZIJSKIH LASTNOSTI \\ NOVO RAZVITIH KOMPOZITOV STEKLO-JEKLO
}

\author{
Olga Lyubimova ${ }^{1}$, Ekaterina Gridasova², Alexander Gridasov², Gerrit Frieling², \\ Martin Klein ${ }^{3}$, Frank Walther ${ }^{3}$ \\ ${ }^{1}$ Department of Mechanics and Mathematical Modeling, Far Eastern Federal University (FEFU), Vladivostok, Russia \\ 2Department of Welding Production, Far Eastern Federal University (FEFU), Vladivostok, Russia \\ ${ }^{3}$ Department of Materials Test Engineering (WPT), TU Dortmund University, Dortmund, Germany \\ gerrit.frieling@tu-dortmund.de
}

Prejem rokopisa - received: 2014-12-17; sprejem za objavo - accepted for publication: 2015-02-17

doi:10.17222/mit.2014.305

\begin{abstract}
This paper presents a preliminary research about a newly developed glass-steel composite created with diffusion welding of glass (C49-1) and carbon steel (St3sp). The main conclusions on the process of forming a diffusion zone during the welding of glass and steel are made. The results of quasi-static and cyclic mechanical tests and corrosion investigations are presented and interpreted on the basis of the microstructure developed during diffusion welding and described in this article.

Keywords: hardening of glass, diffusion welding, glass-steel composite material, tensile tests, cyclic tests, fatigue, corrosion, microstructure

Članek predstavlja uvodne raziskave novo razvitega kompozita steklo-jeklo, izdelanega z difuzijskim varjenjem stekla (C49-1) in ogljikovega jekla (St3sp). Postavljeni so glavni zaključki o postopku nastajanja difuzijske cone med varjenjem stekla in jekla. $\mathrm{Na}$ osnovi razvoja mikrostrukture pri difuzijskem varjenju so predstavljeni in razloženi rezultati kvazi statičnih, cikličnih mehanskih in korozijskih preizkusov.

Ključne besede: utrjevanje stekla, difuzijsko varjenje, steklo-jeklo kompozitni material, natezni preizkusi, ciklični preizkusi,
\end{abstract} utrujenost, korozija, mikrostruktura

\section{INTRODUCTION}

Glass shows a diverging behavior for different kinds of deformation. On the one hand, it has a relatively high compressive strength; however, on the other hand, it has a relatively low tensile strength. The values for the compressive strength of glass are in the range of 500-1250 MPa. So, when working in the compressive mode, glass can compete with the structural-grade carbon steel. At the same time, the tensile strength of glass is much lower: $30-50 \mathrm{MPa} .^{1,2}$ This is due to the fact that the strength of glass is largely dependent on the state of its surface. The most well-known methods for the hardening of glass allow the creation of compressive stresses in the surface layers of glass (glass hardening, ion exchange, surface crystallization) and surface hardening (mechanical polishing, removal of the defective surface layer by etching the glass, application of protective coatings). It is proposed to study the methods, which allow the hardening of glass by eliminating not only the surface micro-defects but also the internal micro-defects, as well as providing insulation from the effects of the environment. ${ }^{3,4}$ As a result, the composite material would be larger and stronger. Diffusion welding ${ }^{5}$ is used widely for joining the elements of simple configuration. It finds a wide application in electronics, aviation and other industries. However, despite the extensive study of the mechanism interaction of various materials during the diffusion welding, a general theory about the relationship between glass and metal has not yet been developed.

The aim of this study is to investigate the mechanical and corrosive properties of this newly developed glasssteel composite material. Therefore, quasi-static, cyclic and potentiodynamic polarization tests are carried out. Furthermore, light microscopic studies are performed to build the basis for microstructure-oriented assessments of the mechanical and chemical results.

\section{EXPERIMENTAL METHODS}

\subsection{Processing of glass-metal composites}

The rod was made as illustrated in Figure 1a. The mobile cover (3) provides holes for gas outlets and the possibility for a forward movement along the longitudinal axis of the shell (2). The movement of the cover (3) is dependent on the shrinkage of the rod (1) during the heating process.

The technological regime (pressure during diffusion bonding $p=0.25 \mathrm{MPa}$ ) is divided into six stages (Figure 


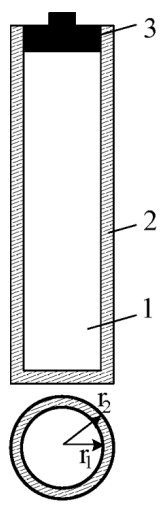

a)

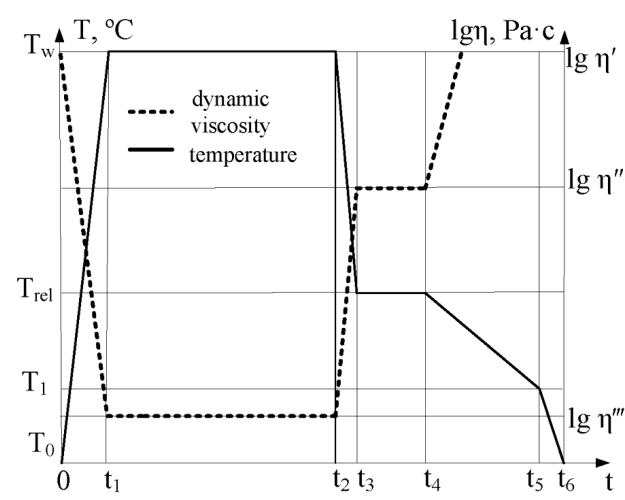

b)
Figure 1: a) Schematic view of a composite rod: 1 - rod of glass C49-1 (3C5Na), 2 - outer shell of steel St3sp, 3 - mobile cover, b) temperature welding: $T$ - temperature welding, $\lg \eta$ - logarithm of the dynamic viscosity of glass

Slika 1: a) Shematski prikaz kompozitne palice: 1 - palica iz stekla C49-1 (3C5Na), 2 - zunanji ovoj iz jekla St3sp, 3 - premični pokrov, b) temperaturno varjenje: $T$ - temperature varjenja, $\lg \eta$ - logaritem dinamične viskoznosti stekla

1b). In the first step, which corresponds to the interval $\left(0, t_{1}\right)$, the composite rod is heated from $T_{0}=20{ }^{\circ} \mathrm{C}$ to the temperature of welding $T_{\mathrm{w}}$ (around $800{ }^{\circ} \mathrm{C}$ ). Given the limited deformation ability of glass to produce a lasting connection, $T_{\mathrm{w}}=T_{\mathrm{g}}$, where $T_{\mathrm{w}}=(0.4 \ldots 0.6) T_{\mathrm{m}}$, with $T_{\mathrm{g}}$ as the temperature of glass softening and $T_{\mathrm{m}}$ as the temperature of the melting metal from which the shell (2) was made. In the interval $\left(t_{1}, t_{2}\right), T_{\mathrm{w}}$ is maintained, providing a reliable connection between glass and steel. It is then cooled down to the temperature of annealing $T_{\text {rel. }}$. To reduce the initial stress, the annealing is carried out in the interval $\left(t_{3}, t_{4}\right)$. This is a necessity at such temperatures, as the viscosity is still quite low, for example, $\eta^{\prime \prime}=10^{12} \mathrm{~Pa} \mathrm{~s}$; the residual stresses are removed after 15 min and, with $\eta^{\prime \prime}=10^{13.5} \mathrm{~Pa} \mathrm{~s}$, after $4 \mathrm{~h}$. In the interval $\left(t_{4}, t_{5}\right)$, the required cooling is carried out up to $T_{1}$, with a rate of $3-5 \mathrm{~K} / \mathrm{min}$. After $\eta^{\prime} \approx 10^{15} \mathrm{~Pa} \mathrm{~s}$, the residual stresses in the glass do not disappear so that at the last stage - the sixth stage - a more rapid cooling at 15-25 $\mathrm{K} / \mathrm{min}$ is possible.

\subsection{Microscopy}

The microstructure of the hybrid material was investigated with light microscopy. Therefore, slices of the specimen were cut off using a cutting wheel. Before using a microscope, these slices were cold mounted, ground and polished.

\subsection{Tensile and fatigue testing}

The quasi-static properties with respect to the compression, tension and torsion of the glass-metal composite, consisting of chemical-laboratory glass brand C49-1 (3C-5Na) and carbon steel St3sp, were determined using a tensile testing system (Shimadzu, $1000 \mathrm{kN}$, UH-I)

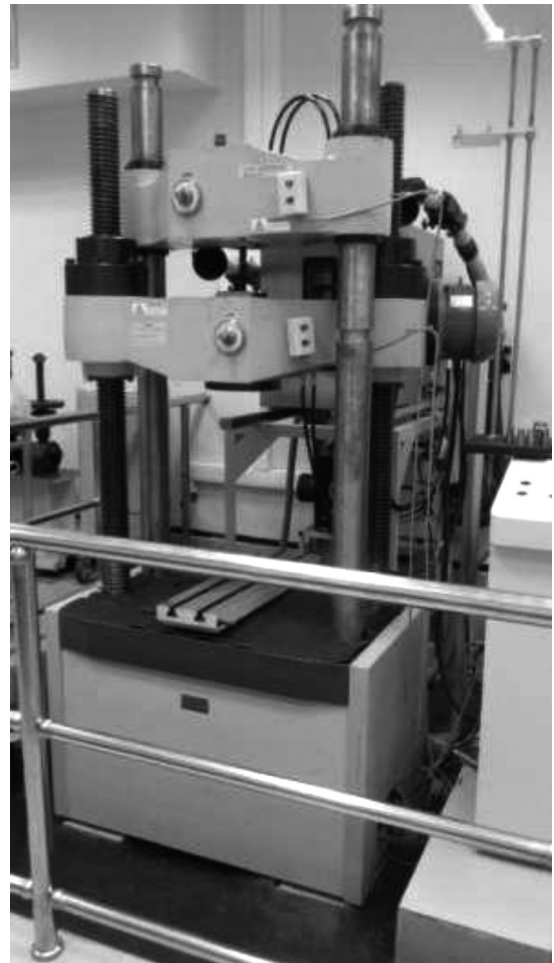

Figure 2: Tensile testing system Shimadzu $1000 \mathrm{kN} \mathrm{UH-I}$ Slika 2: Natezni preizkuševalni sistem Shimadzu 1000 kN UH-I

(Figure 2). Glass $\mathrm{C} 49-1$ has the following chemical composition: $67.5 \% \mathrm{SiO}_{2} ; 20.3 \% \mathrm{~B}_{2} \mathrm{O}_{3} ; 3.5 \% \mathrm{Al}_{2} \mathrm{O}$; $8.7 \% \mathrm{Na}_{2} \mathrm{O}$.

Carbon steel $\mathrm{St} 3 \mathrm{sp}$ comprises the following quantities of the alloying elements: $0.14-0.22 \mathrm{C}$; $0.15-0.30 \mathrm{Si}$; $0.4-0.65 \mathrm{Mn} ; \leq 0.05 \mathrm{~S} ; \leq 0.04 \mathrm{P} ; \leq 0.3 \mathrm{Cr} ; \leq 0.3 \mathrm{Ni}$; $\leq 0.3 \mathrm{Cu} ; \leq 0.08 \mathrm{As} ; \leq 0.01 \mathrm{~N}$.

The geometries of the specimens and their dimensions are shown in Figure 3 and Table 1, respectively.

Table 1: Geometrical characteristics of the specimens, in $\mathrm{mm}$ Tabela 1: Geometrijske značilnosti vzorcev, v mm

\begin{tabular}{|c|c|c|c|c|c|c|c|c|}
\hline$d$ & $l_{0}$ & $l$ & $D$ & $h$ & $r$ & $l_{\mathrm{g}}$ & $d_{\mathrm{g}}$ & $h_{\mathrm{g}}$ \\
\hline 10.0 & 100.0 & 105.0 & 16.0 & 10.0 & 3.0 & 105.0 & 7.5 & 30.0 \\
\hline
\end{tabular}

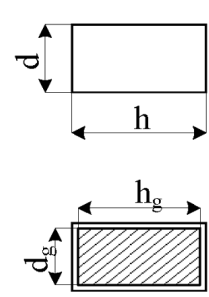

a
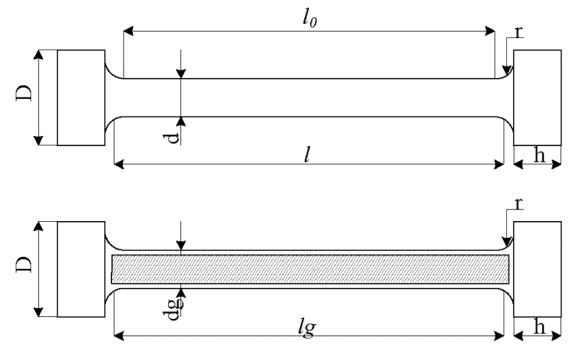

Figure 3: Geometries of the specimens for: a) compression and b) tensile tests

Slika 3: Geometrija vzorcev za: a) tlačni preizkus in b) natezni preizkus 

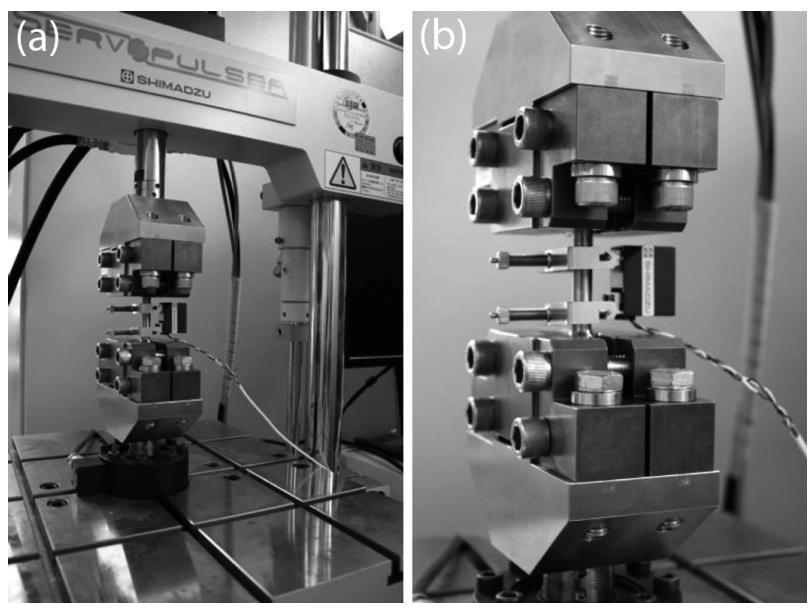

Figure 4: Fatigue testing system: a) overview and b) detail Slika 4: Sistem za preizkušanje utrujanja: a) pregled in b) detajl

For the investigation of the fatigue behavior, loadincrease tests and constant-amplitude tests were performed. ${ }^{6,7}$ The specimens were subjected to a stress ratio of $R=-1$ and a frequency of $f=10 \mathrm{~Hz}$ using sinusoidal load-time functions at room temperature. For the dynamic tests, the specimen geometry shown in Figure 3b was used. In order to measure the total strain and to determine the plastic-strain amplitude, an extensometer was attached to the specimen.

Figure 4 shows a specimen mounted onto the servohydraulic testing system (Shimadzu, $20 \mathrm{kN}$, EHF-LV20) with the attached extensometer. The testing system has the maximum load capacity of $20 \mathrm{kN}$ and the extensometer has a range of $\pm 4.0 \%$ of the total strain. The fatigue strength of the glass-metal composite rod for the ultimate number of cycles $N_{\text {limit }}=2 \cdot 10^{6}$ was estimated with a stepwise load-increase test according to the

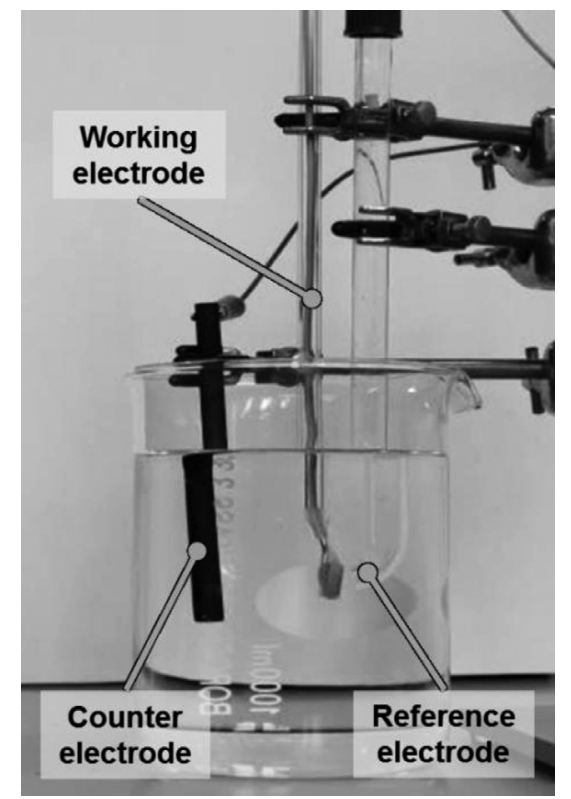

Figure 5: Potentiodynamic-polarization measurement set-up Slika 5: Sistem za merjenje potenciodinamične polarizacije measured material response and afterwards validated with constant-amplitude tests.

\subsection{Corrosion testing}

The corrosion behavior of the St3sp steel and of the hybrid interface was investigated with potentiodynamic polarization measurements in a $0.1 \mathrm{~mol} \mathrm{~L}^{-1} \mathrm{NaCl}$ solution at $\mathrm{pH} 7$; the $\mathrm{pH}$ values were adjusted using a 0.1 mol L ${ }^{-1} \mathrm{KOH}$ solution. A standard three-electrode system, consisting of a saturated calomel electrode (SCE) as the reference electrode and a graphite electrode as the counter electrode, was used for the measurements ${ }^{8}$. As the working electrodes, the St3sp steel and the cross-section of a round specimen (Figure 3b) for fatigue testing were used. The specimens were abraded with emery paper of 18-5 $\mu \mathrm{m}$. Then, a copper wire was attached to the specimens and the whole specimens, except for their front sides, were embedded in the epoxy resin. Before each polarization measurement, the electrolyte was purged for 30 min with argon and afterwards the opencircuit potential was measured for $30 \mathrm{~min}$. The measurements were conducted using a potentiostat (Gamry, PCI4300) at a scanning rate of $0.1 \mathrm{mV} / \mathrm{s}$. The experimental set-up of the potentiodynamic-polarization measurements is shown in Figure 5.

\section{RESULTS AND DISCUSSION}

\subsection{Microstructure}

The St3sp steel was found to have a ferritic structure with around $8 \%$ of pearlite. After polishing and analyzing the border-welding zones of the samples, there were still no visible cracks or voids. The analysis of microsections showed the presence of a full contact without cracks or spills in the welding zone (Figure 6). The microscopic examination of the welding zone clearly shows a development of the interaction at the boundary of the contact. A bright zone in the glass confirms this development. The results of the spectral analysis indicate a penetration of cations into the glass to a depth of 30 microns and more. This is in accordance with the results

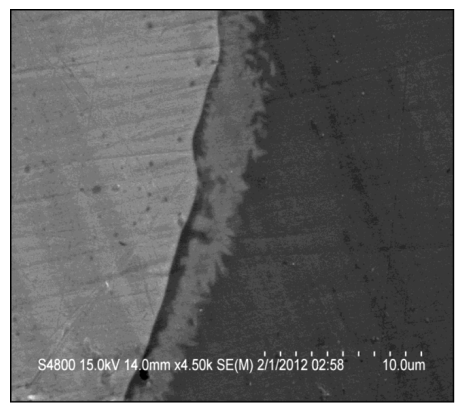

a)

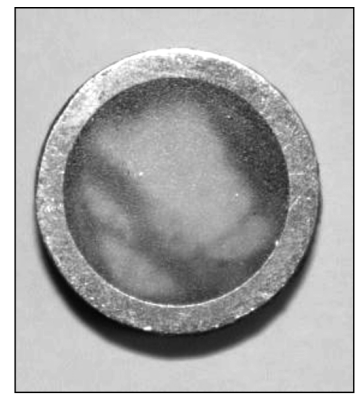

b)
Figure 6: a) Micrograph of the welded joint between metal and glass, b) micrograph of the cross-section

Slika 6: a) Posnetek področja zvarjenega spoja med kovino in steklom, b) posnetek preseka 


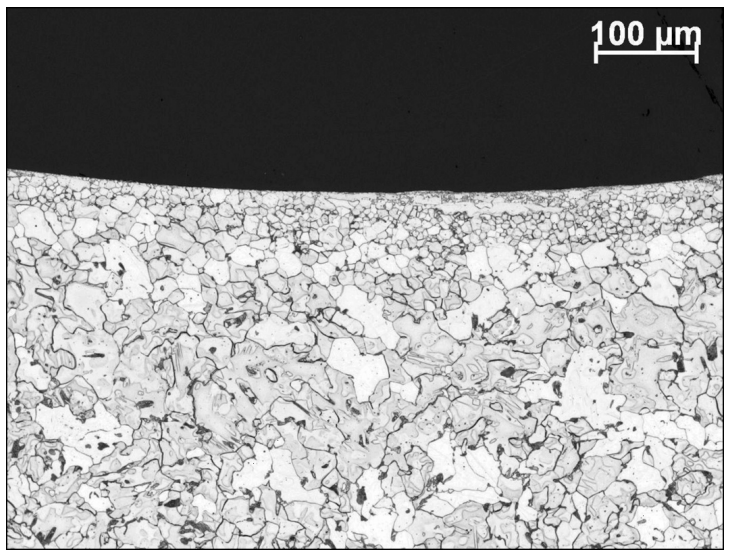

Figure 7: Micrograph of the grains in the transition area between steel and glass

Slika 7: Posnetek zrn v jeklu v prehodnem področju v steklo

of the corrosion tests, which also indicated the formation of the glass-metal phase.

Figure 7 shows the grains in the transition area between steel and glass. It is apparent that the grain size of the ferritic structure in close vicinity of the glass is smaller than at bigger distances. The explanation for this behavior has not been found yet, but it will be a topic of further investigations of this glass-steel composite material.

\subsection{Deformation behavior}

By performing the compression, tensile and torsional tests, the quasi-static properties of the selected glass, the steel and the glass-steel composite were determined. The stress-strain curves for compression and tension of the composite material are depicted in Figure 8. The results for different materials and tests are shown in Tables 2 and 3.

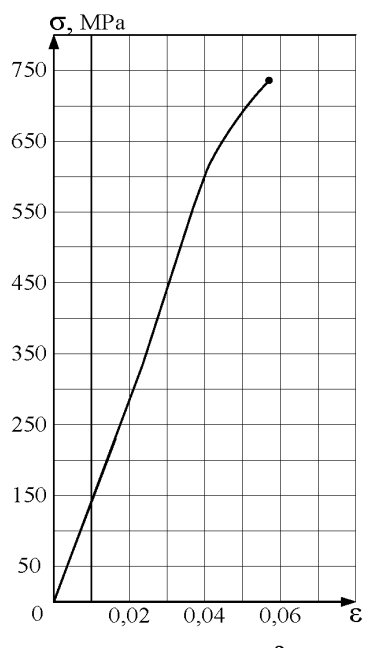

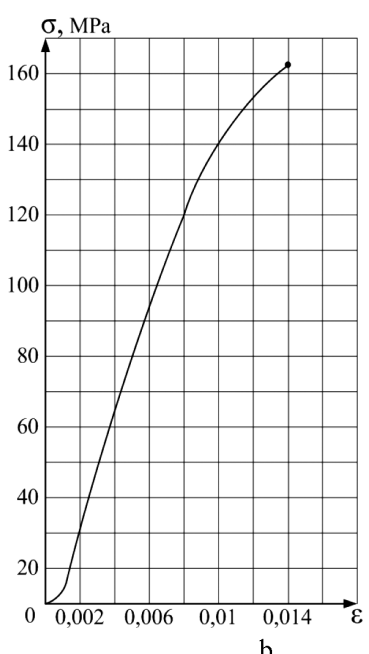

Figure 8: Stress-strain curve of the glass-metal composite for: a) compression and b) tension

Slika 8: Krivulja napetost - raztezek kompozita steklo-kovina pri: a) tlačnem in b) nateznem preizkusu
The maximum compressive stress of the composite material is more than 13 times higher than the maximum compressive stress of the C49-1 glass and it is twice as high as for the St3sp carbon steel. The maximum tensile stress of the composite sample is twice as much as that of glass and half of that of carbon steel. The Young's modulus and shear modulus of the composite have intermediate values of the modules of the base materials, glass and steel.

Table 2: Mechanical characteristics of base materials and glass-steel composite rod

Tabela 2: Mehanske značilnosti osnovnih materialov in kompozitne palice steklo-jeklo

\begin{tabular}{|c|c|c|c|}
\hline & & $F_{\max } / \mathrm{kN}$ & $\sigma_{\max } / \mathrm{MPa}$ \\
\hline Glass (C49-1) & $\begin{array}{c}\text { compressive } \\
\text { strength }\end{array}$ & 2.55 & 55.00 \\
\hline Glass (C49-1) & tensile strength & 3.40 & 77.00 \\
\hline Steel (St3sp) & $\begin{array}{c}\text { compressive } \\
\text { strength }\end{array}$ & 30.05 & 389.20 \\
\hline Steel (St3sp) & tensile strength & 29.00 & 368.96 \\
\hline $\begin{array}{c}\text { Composite } \\
\text { glass-steel }\end{array}$ & $\begin{array}{c}\text { compressive } \\
\text { strength }\end{array}$ & 58.50 & 745.00 \\
\hline $\begin{array}{c}\text { Composite } \\
\text { glass-steel }\end{array}$ & tensile strength & 12.70 & 162.00 \\
\hline
\end{tabular}

Table 3: Mechanical characteristics of base materials and glass-steel composite rod

Tabela 3: Mehanske značilnosti osnovnih materialov in kompozitne palice steklo-jeklo

\begin{tabular}{|c|c|c|c|}
\hline & Glass (C49-1) & Steel (St3sp) & $\begin{array}{c}\text { Composite } \\
\text { glass-steel }\end{array}$ \\
\hline $\begin{array}{c}\text { Young's } \\
\text { modulus, (MPa) }\end{array}$ & $0.73 \cdot 10^{5}$ & $2.10 \cdot 10^{5}$ & $1.40 \cdot 10^{5}$ \\
\hline $\begin{array}{c}\text { Shear modulus, } \\
(\mathrm{MPa})\end{array}$ & $0.30 \cdot 10^{5}$ & $0.80 \cdot 10^{5}$ & $0.56 \cdot 10^{5}$ \\
\hline
\end{tabular}

\subsection{Fatigue beahvior}

For an evaluation of the cyclic-deformation behavior and for an estimation of the fatigue strength, a stepwise load-increase test was performed with a glass-metal composite specimen as depicted in Figure 9. During this test, the plastic-strain amplitude was measured as the parameter of the material reaction, which characterizes the proceeding fatigue damage as the basis for the estimation of the fatigue strength. ${ }^{9}$ The estimation of the fatigue strength was validated with constant-amplitude tests, whose lifetimes (the number of cycles to failure) are shown with the $S$ - $N$ curve.

Starting at $\sigma_{\mathrm{a} \text {,start }}=6.4 \mathrm{MPa}$, the stress amplitude was increased by $6.4 \mathrm{MPa}$ each $10^{4}$ cycles until failure. The plastic-strain amplitude $\varepsilon_{\mathrm{a}, \mathrm{p}}$ increases slightly within the first nine steps, but remains almost constant within each step. In the tenth step, there is a visible increase compared to the ninth step, but the plastic-strain amplitude still does not increase within the step. This is different for the eleventh step at the stress amplitude of $70.4 \mathrm{MPa}$. In the twelfth step, there is a considerable increase of the 


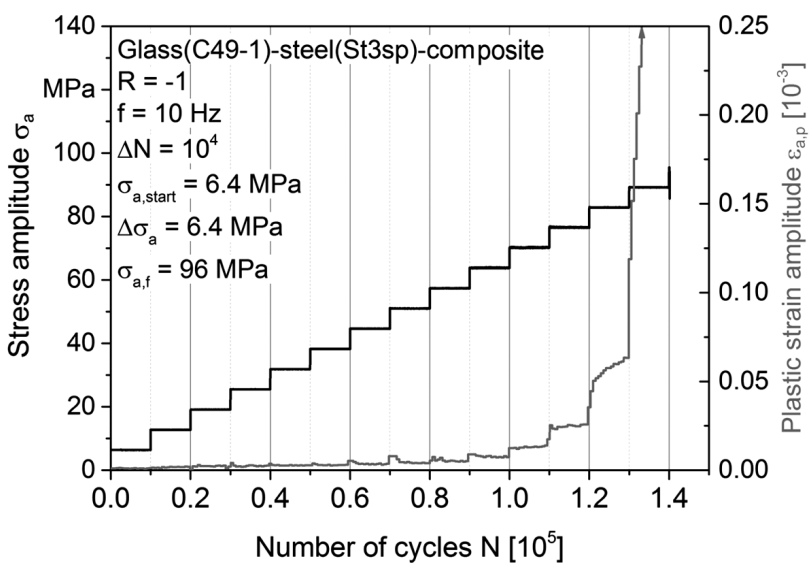

Figure 9: Stepwise load-increase test with a glass-metal composite Slika 9: Preizkus stopničastega naraščanja obremenitve kompozita steklo-jeklo

plastic-strain amplitude and, finally, there is an exponential increase in the thirteenth step.

As the fatigue strength is linked to the first increase in the material-reaction quantity within one step, ${ }^{9}$ the estimate from this load-increase test for the endurance limit is $70 \mathrm{MPa}$. This estimation was validated with the constant-amplitude tests with $N_{\text {limit }}=2 \cdot 10^{6}$ as the ultimate number of cycles. Ten tests with different stress amplitudes were conducted and the results are shown as an $S$ - $N$ curve in Figure 10. The highest stress amplitude used is $127 \mathrm{MPa}$, which is close to the tensile strength of $162 \mathrm{MPa}$ (Table 3) for the glass-metal composite. The specimen with a load amplitude of $64 \mathrm{MPa}$ reached the ultimate number of cycles without fracture.

For this set of specimens, the modified Basquin equation was found to be $\sigma_{\mathrm{a}}=245 \mathrm{MPa}\left(N_{\mathrm{f}}\right)^{-0.09}$.

If the estimation of the fatigue strength from the load-increase test $(70 \mathrm{MPa})$ is compared to the highest stress amplitude without failure (64 MPa), it becomes apparent that the estimation on the basis of the plastic-strain amplitude is a very suitable tool for this

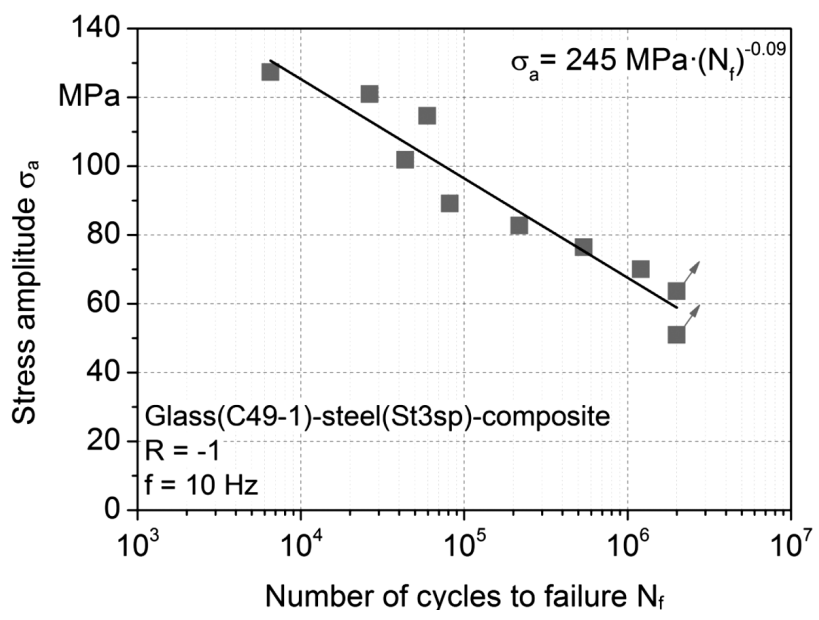

Figure 10: $S-N$ curve for glass-steel composite Slika 10: $S$ - $N$-krivulja za kompozit steklo-jeklo

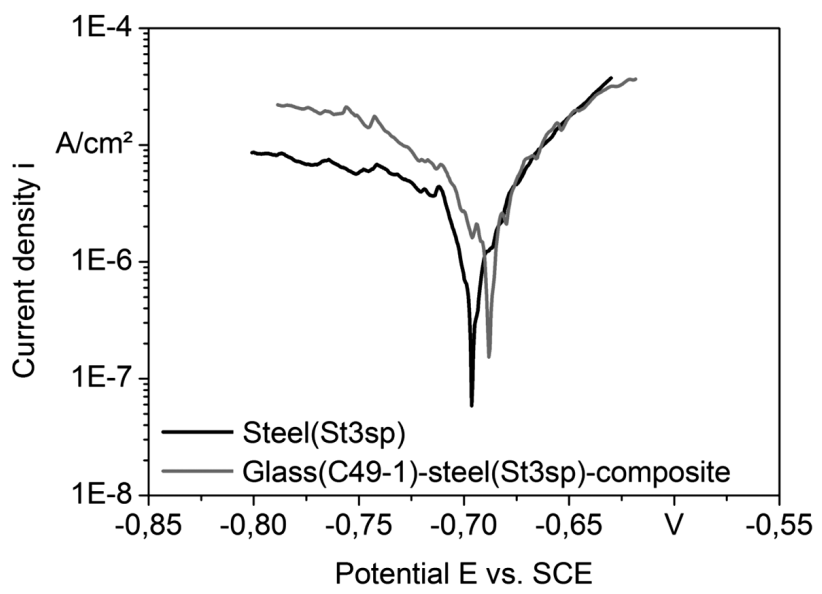

Figure 11: Tafel plots of the metal jacket and glass-steel composite Slika 11: Taflov diagram kovinskega ovoja in kompozita steklo-jeklo

composite material, with only one specimen. The stress amplitude of the highest run-out specimen is about $40 \%$ of the tensile strength of the composite material.

\subsection{Corrosion behaviour}

Figure 11 shows the Tafel plots for the steel jacket and the hybrid interface between glass and steel. The steel jacket shows a marginally less noble corrosion potential $E_{\text {corr }}$ than the hybrid interface. However, the corrosion current density $i_{\text {corr }}$ (i.e., the corrosion rate) of the glass-metal joint is approximately four times higher than that of the metal jacket. Consequently, the welding of glass and metal influences the corrosion resistance, suggesting that a glass-metal phase is formed through the welding process.

\section{CONCLUSIONS}

The formation of a glass-metal phase was determined with micrographs and corrosion tests. Furthermore, a dependency of the steel grains as a function of the distance to the transition zone was found. The newly developed glass-metal composite material has quasi-static properties, comparable to those of the St3sp steel. Using a stepwise load-increase test and constant-amplitude tests, the endurance limit of the composite was evaluated as $70 \mathrm{MPa}$. This value is about $40 \%$ of its tensile strength. The corrosion rate of the composite material was ascertained to be four times higher than the corrosion rate of the St3sp carbon steel.

This glass-metal material has potential applications, especially for compressive loads, for example, in civil engineering. The analysis of the glass-metal phase, the examination of the grain-size distribution in the carbon steel near the transition zone as well as the mechanical investigations with a superimposed corrosive impact during the cyclic testing, i.e., corrosion-fatigue investigations, are planned as the further investigation steps. 


\section{Acknowledgements}

The study was supported by the Federal Program "Nanosystems" Activity 1.2, contract № 14.575.21.0009, unique identifier ASR RFMEFI57514X0009.

\section{REFERENCES}

${ }^{1}$ V. P. Pukh, L. G. Baikova, M. F. Kireenko, L. V. Tikhonova, T. P. Kazannikova, A. B. Sinani, Atomic structure and strength of inorganic glasses, Physics of the Solid State, 47 (2005) 5, 876-881, doi: $10.1134 / 1.1924848$

${ }^{2}$ E. A. Gridasova, Increase of strength properties of glass as a result of metallization by diffusion welding, $\mathrm{Ph}$. D. Dissertation, Vladivostok, 2013, 134

${ }^{3}$ E. A. Gridasova, O. N. Lyubimova, K. N. Pestov, G. L. Kayak, Patent №2428389 RF, MPK C03C 27/02, Method of making steklometallokompozita - №2009149794, Zayav. 31.12.2009, Publ. 10.09.2011, Bul. № 25, 6
${ }^{4}$ O. N. Lyubimova, E. A. Gridasova, Method of hardening during diffusion bonding of glass to the metal, Welding and diagnostic materials, 2010, № 6, 31-45

${ }^{5}$ V. A. Bachin, Theory, technology and diffusion welding equipment M: Mechanical Engineering, 1991, 352

${ }^{6} \mathrm{~F}$. Walther, Microstructure-oriented fatigue assessment of construction materials and joints using short-time load increase procedure, MP Materials Testing, 56 (2014) 7-8, 519-527, doi:10.3139/120. 110592

${ }^{7}$ F. Walther, D. Eifler, Cyclic deformation behavior of steels and light-metal alloys, Materials Science and Engineering A, 468-470 (2007), 259-266, doi:10.1016/j.msea.2006.06.146

${ }^{8}$ P. Wittke, M. Klein, F. Walther, Corrosion Fatigue Behaviour of Creep-Resistant Magnesium Alloy Mg-4Al-2Ba-2Ca, Procedia Engineering, 74 (2014), 78-83, doi:10.1016/j.proeng.2014.06.228

${ }^{9}$ P. Starke, F. Walther, D. Eifler, "PHYBAL": a short-time procedure for a reliable fatigue-life calculation, Advanced Engineering Materials, 12 (2010) 4, 276-282, doi:10.1002/adem.200900344 